\title{
Echinocotyle capensis n.sp. (Cestoda: Hymenolepididae) from South African waterfowl
}

\author{
J. D. McLaughlin \\ Biology Department, Concordia University, 1455 de Maisonneuve Boulevard West, Montréal, Que., Canada H3G 1 M8
}

Received July 12, 1988

McLaughuin, J. D. 1989. Echinocotyle capensis n.sp. (Cestoda: Hymenolepididae) from South African waterfowl. Can. J. Zool. 67: $1749-1751$.

Echinocotyle capensis n.sp. is described from Cape shovelers (Anas smithii (Hartert)) and Cape teal (Anas capensis Gmelin) collected at Barberspan, Transvaal Province, Republic of South Africa. Echinocotyle capensis is a small cestode up to $1.62 \mathrm{~mm}$ long with 10 rostellar hooks 50-55 $\mu \mathrm{m}$ long. It most closely resembles Echinocotyle singhi Srivastava and Pandey, 1980 but has slightly longer rostellar hooks and a shorter cirrus sac, and lacks the vaginal sphincter present in $E$. singhi.

McLaughuin, J. D. 1989. Echinocotyle capensis n.sp. (Cestoda: Hymenolepididae) from South African waterfowl. Can. J. Zool. $67: 1749-1751$.

On trouvera ici la description d'Echinocotyle capensis n.sp. trouvé chez des Souchets du Cap (Anas smithii (Hartert)) et chez des Sarcelles du Cap (Anas capensis Gmelin) capturés à Barberspan, Province du Transvaal, Afrique du Sud. Echinocotyle capensis est un petit cestode pouvant atteindre $1,62 \mathrm{~mm}$ de longueur et portant des crochets rostellaires de $50-55 \mu \mathrm{m}$ de longueur. L'espèce ressemble surtout à Echinocotyle singhi Srivastava et Pandey, 1980, mais ses crochets rostellaires sont légèrement plus longs, la poche de son cirre est plus courte et elle ne possède pas le sphincter vaginal présent chez E. singhi.

[Traduit par la revue]

\section{Introduction}

During a study of helminths from Cape Teal (Anas capensis Gmelin) and Cape Shoveler (Anas smithii (Hartert)) from Barberspan, Transvaal, Republic of South Africa, several species of cestodes belonging to the genus Echinocotyle Blanchard, 1891, were found. One of these represents an undescribed species and is described herein.

\section{Materials and methods}

The specimens were part of a larger collection of helminths from anatids obtained in November and December 1978 at the Barberspan Ornithological Research Station in the western Transvaal, Republic of South Africa. Ducks were collected locally by shooting and examination was begun within 15 min of death. Cestodes found were rinsed in tap water, fixed in $10 \%$ formalin $(24 \mathrm{~h})$, and then stored in $70 \%$ ethanol. Specimens were stained in acetocarmine and mounted in Canada Balsam. Measurements and drawings were made on a Wild M-20 microscope with an attached drawing tube. All measurements are in micrometres unless indicated otherwise. Values in parentheses represent the mean. The ovary, vitelline gland, seminal receptacle, and external seminal vesicle were normally seen in only two adjacent proglottids, in immature form in the more anterior and in mature form in the other. Accordingly, means were not calculated for measurements of these characters.

\section{Echinocotyle capensis n.sp.}

(Figs. 1-6)

With characteristics of the genus. The description is based on 12 complete specimens exhibiting uterine development.

Small cestodes $0.68-1.62(0.94) \mathrm{mm}$ long by $0.1-0.21$ $(0.16) \mathrm{mm}$ in maximum width. Strobilae with $10-22$ (13) proglottids consisting of 5-12 (7) immature proglottids, $1-7$ mature proglottids (3), and 2-6 (4) proglottids exhibiting uterine development. No fully gravid specimens were found.

Scolices (Fig. 1), measured from the base of the rostellar sac to the tip of the rostellar sheath, 168-240 (201) long by 89-117 (101) wide. Rostellar sheath 60-96 (77) long. Base of rostellar sac even with or extending up to 40 posterior to the suckers. Retracted rostellum 120-187 (157) long armed with 10 hooks 50-55 (53) long (Fig. 2). Blade and handle of hook of approximately equal length. Suckers oval, weakly muscled, $79-91$ (85) long by 29-43 (36) wide and armed with hooks $7-10$ (8.5) long (Fig. 3). Hooks arranged in transverse rows on sucker periphery: 2 or 3 per row near the anterior, 3 or 4 per row along the lateral margin, and $1-3$ per row near posterior margin. The rows of hooks apparently not confluent at the posterior edge of the sucker. Hooks in sucker cavity apparently easily lost; some specimens lacked hooks completely; 3-11 hooks were found in others. These occurred in 1 staggered (or perhaps 2 separate) vertical row near the middle of the sucker cavity.

Testes spherical to subspherical $19-30(22) \times 20-31(23)$ in mature proglottids (Fig. 4). Poral and middle testes side by side in posterior half of proglottid; antiporal testis deflected slightly anterior. Testes appear 1 or 2 proglottids before cirrus sac. Cirrus sac $72-120$ (102) long by 12-24 (18) wide, cylindrical, with muscular walls, extending to or beyond antiporal excretory vessels in mature proglottids. In uterine proglottids, cirrus sac may also extend to or beyond antiporal vessels but more frequently extends only into the middle third of the proglottid. External seminal vesicle oval to pyriform, dorsal to cirrus sac, 30-52 $\times 21-35$. External seminal vesicle fills rapidly (Fig. 4). Internal seminal vesicle also fills rapidly, being virtually empty in one proglottid and full in the next. When full, it occupies most of the cirrus sac. Cirrus (Fig. 5) tubular, 32-39 (36) long by 3-4 in diameter along its length, tapering abruptly near the tip. Cirrus sparsely covered with a uniform layer of minute spines. Accessory sac oval, 22-33 (25) $\times 11-26$ (18) dorsal to cirrus sac with spinose eversible portion (Fig. 5) up to $33 \times 7$ when everted (Fig. 6). Eversible portion densely covered with small spines and with a row of longer spines encircling the base (Fig. 6).

Ovary irregularly oval, $30-45$ broad by $15-25$ long, located in antiporal half of proglottid ventral to middle testis. Vitelline gland subspherical, postovarian, $12-17 \times 10-14$. Vagina enters genital atrium ventrally to cirrus sac. Copulatory portion of vagina 24-30 long. Seminal receptacle oval, $30-38 \times 18-26$ when full. Uterus saccular extending beyond excretory vessels. Mature eggs not found.

TYPE HOST: Anas smithii (Hartert). 

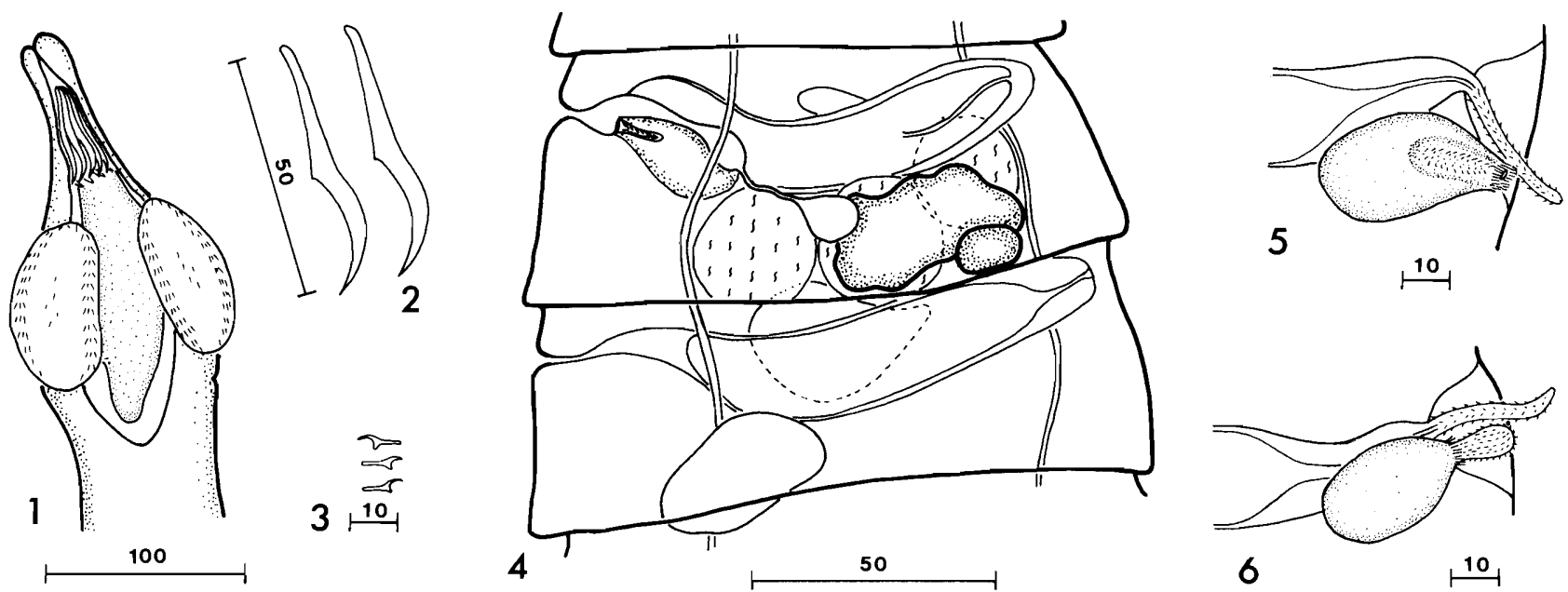

FIGS. 1-6. Echinocotyle capensis n.sp. Fig. 1. Scolex. Fig. 2. Rostellar hooks. Fig. 3. Sucker hooks. Fig. 4. Mature proglottids. Top proglottid shows general morphology; bottom proglottid illustrates the rapid filling of the external seminal vesicle, internal seminal vesicle, and seminal receptacle. Fig. 5. Cirrus and accessory sac. Fig. 6. Cirrus and accessory sac with spinous portion everted. All scale bars in micrometres.

OTHER HOST: Anas capensis Gmelin.

SITE: Small intestine.

TYPE LOCALITY: Barberspan, Transvaal, Republic of South Africa.

HOLOTYPE: National Museum of Natural Sciences, Canada, Invertebrate Collection (Parasites), No. NMCP1988-0890. PARATYPES: Nos. NMCP1988-0891-0894.

\section{Discussion}

There are eight species in the genus Echinocotyle that have 10 rostellar hooks that either overlap the length of those on $E$. capensis or are sufficiently close $(53 \pm 10 \mu \mathrm{m})$ to warrant consideration. These include $E$. brachycephala (Creplin, 1829), E. hypoleuci Singh, 1952, E. ibanezi Rego, 1973, E. oweni Moghe, 1933, E. quasioweni (Dubinina, 1954), E. singhi Srivastava and Pandey, 1980, E. uralensis Clerc, 1902, and E. verschureni (Baer, 1959). Of these, only $E$. brachycephala, $E$. oweni, and $E$. singhi have been reported from anseriformes. Echinocotyle brachycephala and $E$. oweni also occur in charadriiformes (Schmidt 1986). With the exception of E. singhi $(0.645-0.87 \mathrm{~mm}$ long, Srivastava and Pandey 1980) all of the other species are much larger than E. capensis (Krabbe 1869; Spasskaya 1966; Singh 1952; Rego 1973; Moghe 1933; Dubinina 1954; Clerc 1902; Baer 1959). Strobilae ranging from 25 to $72 \mathrm{~mm}$ long occur among these species (see references above) and $E$. capensis can be readily distinguished from them on the basis of strobilar length alone.

Echinocotyle singhi resembles E. capensis in general size but can be distinguished from it on the basis of its smaller rostellar hooks $(38-49)$ and its larger cirrus sac $(143-157)$, and by the presence of a large sphincter $(21-24 \times 17-24)$ surrounding the copulatory portion of the vagina. The sphincter is lacking in the new species.

An additional species, Echinocotyle fimbriata Spasskii and Yurpalova, 1971, described from charadriiformes and lacking a scolex, is similar in size $(4-6 \mathrm{~mm})$ to $E$. capensis. It possesses a row of finger like extensions around the genital opening (Spasskii and Yurpalova 1971) and is easily distinguished from $E$. capensis on this basis.
Kornyushin (1983) recently subdivided the genus Echinocotyle into five subgenera. If this division is accepted, E. capensis would belong to the subgenus Echinocotyle, which is reserved for small species with few proglottids, an armed cirrus, and an accessory sac (Fuhrmann body) with a row of spines around its aperture. Species included within this subgenus are all parasites of anseriformes (Komyushin 1983).

\section{Acknowledgements}

I would like to acknowledge the efforts of the late David Skead who arranged the trip to Barberspan and who, along with John Mitchell, collected most of the ducks. I would also like to thank the Skead family for their generous hospitality during my stay. Irene Menaggia generously translated the Russian articles. This work was supported by a Natural Sciences and Engineering Research Council of Canada grant (A6979).

BAER, J. G. 1959. Helminthes parasites. Exploration des parcs nationaux du Congo Belge, Mission J. G. Baer - W. Gerber (1958). Vol. 1. Institut des Parcs nationaux du Congo Belge, Tervuren, Belgium.

Clerc, W. 1902. Contribution à l'étude de la faune helminthologique de l'Oural. I. Zool. Anz. 25: 569-575.

Dubinina, M. N. 1954. Cestodes of birds nesting in western Siberia. (In Russian.) Parazitol. Sb. 15: 117-233.

Kornyushin, V. V. 1983. Analysis of the structure of the genus Echinocotyle (Cestoda, Hymenolepididae). (In Russian.) Parazitologiya (Leningr.), 14: 268-271.

KrabBE, H. 1869. Bidrag til kundskab om Fulgenes Baendelorme. K. Dan. Vidensk. Selsk. Skr. Naturvidensk. Math. Afd. 8: 249-363.

Moghe, M. A. 1933. Four new species of avian cestodes from India. Parasitology, 25: 333-341.

Rego, A. A. 1973. Echinocotyle ibanezi sp.n. parasito de ave do Péru (Cestoda, Hymenolepididae). Atas Soc. Biol. Rio de Janeiro, 16: $63-65$.

SCHMIDT, G. D. 1986. Handbook of tapeworm identification. CRC Press, Boca Raton, FL.

SinGH, K. S. 1952. Cestode parasites of birds. Indian J. Helminthol. 4: $1-72$. 
Srivastava, V. C., and Pandey, G. P. 1980. A new species Echinocotyle singhi n.sp. (Cestoda, Hymenolepididae) from the bluewinged teal, Querquedula circa from Allahabad (India). Proc. Indian Acad. Parasitol. 1: 45-48.

SPASSKaYA, L. P. 1966. Cestodes of birds of the U.S.S.R. Hymeno- lepididae. (In Russian). Izdatel'stvo Nauka Akademiia Nauk SSSR Akademiia Nauk Moldavia SSR Institut Zoologiya, Moskva.

SpasskiI, A. A., and YurPalova, N. M. 1971 (for 1969). Hymenolepids of birds in Vietnam. (In Russian.) Helminthologia, 10: 203-243. 